\title{
Клінічний випадок "защемлення" колоноскопа в грижовому мішку у хворого з лівобічною пахвинно-калитковою грижею
}

\author{
У статті представлено унікальний клінічний випадок, особливості клініки, діагностики та хірургічного лікування “защемлен- \\ ня” колоноскопа в грижовому мішку у хворого з лівобічною пахвинно-калитковою грижею.
}

Ключові слова: “защемлення” колоноскопа; грижовий мішок; пахвинно-калиткова грижа.

У структурі ургентної хірургічної абдомінальної патології защемлена грижа займає 2-ге місце після гострого апендициту. Від гриж страждають 12-14 осіб на 10000 населення. Летальність при защемлених грижах становить 2-4 \%.

У літературі описано такі рідкісні види гриж: грижі лінії Spieghel, поперекові грижі, грижі затульного отвору, сідничні грижі, грижі промежини.

Науковці також виділяють особливі види защемлення - ретроградне і пристінкове. При ретроградному защемленні здавлюються не петлі кишок, які містяться в грижовому мішку, а петля, що вийшла з грижових воріт у вільну черевну порожнину. Тому в грижовому мішку, як правило, розташовані дві незмінені петлі кишки. Ретроградне защемлення перебігає тяжко, оскільки некроз, перитоніт розвиваються не в замкнутому грижовому мішку, а у вільній черевній порожнині. Пристінкове защемлення (грижа Ріхтера) характеризується тим, що защемлюється не вся петля кишки, а лише частина ії стінки, розташована по вільному, протилежному до брижового, краю. При цьому розвивається не механічна кишкова непрохідність, а некроз стінки защемленої кишки.

Представляємо унікальний клінічний випадок, особливості клініки, діагностики та хірургічного лікування “защемлення” колоноскопа в грижовому мішку хворого $з$ лівобічною пахвинно-калитковою грижею.

У хірургічне відділення К3 ТОР “Тернопільська університетська лікарня” для планової герніопластики госпіталізовано пацієнта В., 1935 р. н. із скаргами на пухлиноподібне випинання в лівій пахвинно-калитковій ділянці, збільшення в розмірах калитки, частий біль при фізичному навантаженні, що змушувало хворого змінювати положення тіла на лежаче.

3 анамнезу захворювання: вважає себе хворим протягом 4-х років, коли поступово почав відмічати появу даного утвору та збільшення його в роз- мipax. У зв'язку з постійним больовим синдромом, частими защемленнями звернувся по допомогу до хірурга.

3 анамнезу життя відомо, що пацієнту в 2010 р. виконано операцію - передню резекцію прямої кишки з накладанням первинно-нефункціонуючого анастомозу, трансверзостомію, дренування черевної порожнини з приводу C-r recti. Через три місяці - операція - реконструкція трансверзостоми. У тому ж році проведено трансуретральну резекцію простати. У 2013 р. - металоостеосинтез із приводу перелому стегнової кістки в ділянці головки.

Об'єктивно: у лівій пахвинно-калитковій ділянці грижоподібне випинання 12x8 см, вміст невправимий в черевну порожнину, опускається в калитку, симптом кашльового поштовху позитивний, шкіра над грижовим випинанням не змінена. Калитка зліва збільшена в розмірах, в проекції яєчка вивлено ущільнення до 8 см у діаметрі, болючість при пальпації яєчка та його придатків, гіперемія та помірний набряк калитки, при діафаноскопії наявна водянка лівого яєчка.

Після виконання всіх передопераційних обстежень згідно з алгоритмом для даної патології, консультації суміжних спеціалістів хворому встановлено діагноз: “Лівобічна набута невправима коса пахвинно-калиткова грижа. Водянка лівого яєчка. Орхіепідидиміт зліва? C-r recti, III клінічна група. IXC. Ат. Кардіосклероз. Атеросклеротична артеріальна гіпертензія. СН - I стадії, II ФК.

Разом 3 тим, враховуючи пухлинний анамнез, вирішено провести контрольний огляд товстої кишки, який ректороманоскопічно оглянути не вдається у зв'язку з остеосинтезом кульшового суглоба та обмеженням рухомості в ньому. Тому вирішено провести колоноскопію. Хворому проведено підготовку до обстеження препаратом “Мовіпреп” та очисними клізмами.

Під час колоноскопії вільно оглянуто всі відділи товстого кишечника - патології не виявле- 


\section{ПОВІДОМЛЕННЯ}

но. Спроби поступово вивести колоноскоп з кишечника не вдавалися. При пальпації виявлено, що його частина міститься в грижовому мішку, утворивши петлю. Спроби вивести його бімануальним методом не дали успіху. Проведено рентгенографію та виявлено, що кінець колоноскопа, пройшовши при огляді через сигмоподібну кишку, що міститься в калитці, утворив вузол у грижовому мішку.

Вирішено виконати операційне втручання за ургентними показаннями.

Під внутрішньовенним наркозом з інтубацією та ШВЛ виконано доступ у лівій здухвинній ділянці, виділено грижовий мішок, розкрито. Виділено із множинних злук із грижового мішка петлю сигмоподібної кишки. Розсічено грижові ворота, що дало змогу мануально внутрішньокишково ліквідувати петлю колоноскопа та вивести колоноскоп через пряму кишку назовні. При виділенні яєчка від грижового мішка виявлено змінений придаток яєчка та яєчко синюшного кольору 3 наявністю близько 5 мл осумкованого гною. Враховуючи наявність водянки яєчка, зміни з боку сім'яного канатика, яєчка та придатка яєчка, вік хворого, проведено інтраопераційний консиліум з урологами та вирішено провести орхектомію зліва. Виконано

\section{СПИСОК ЛІТЕРАТУРИ}

1. Современные аспекты лечения больных с боковыми и передне-боковыми грыжами живота / С. Ю. Пушкин, В. И. Белоконев, Ю. В. Пономарева, Л. Т. Волова // Вестник хирургии им. И.И. Грекова. - 2010. - Т. 109, № 2. - С. 26-30. 2. Мішалов В. Г. Десятирічний досвід оперативних втручань у пацієнтів з післяопераційними передньо-боковими грижами / В. Г. Мішалов, А. О. Бурка, Л. Ю. Маркулан // AML XV. - 2009. - № 3. - C. 84-88.

\section{REFERENCES}

1. Pushkyn, S.Iu., Belokonev, V.Y., Ponomareva, Iu.V., \& Volova L.T. (2010). Sovremennyie aspekty lecheniia bolnykh s bokovymi i peredne-bokovymi grizhami zhyvota [Modern aspects of treatment of patients with lateral and anteriolateral abdominal hernia]. Vestnik khirurhii im. I.I. Grekova. - Herald of Surgery by I.I. Grekov, 109 (2), 26-30.

2. Mishalov, V.H., Burka, A.O., \& Markulan L.Yu. (2009). Desiatyrichnyi dosvid operatyvnykh vtruchan u patsiientiv z pisliaoperatsiinymy peredno-bokovymy hryzhamy [Ten year experi-

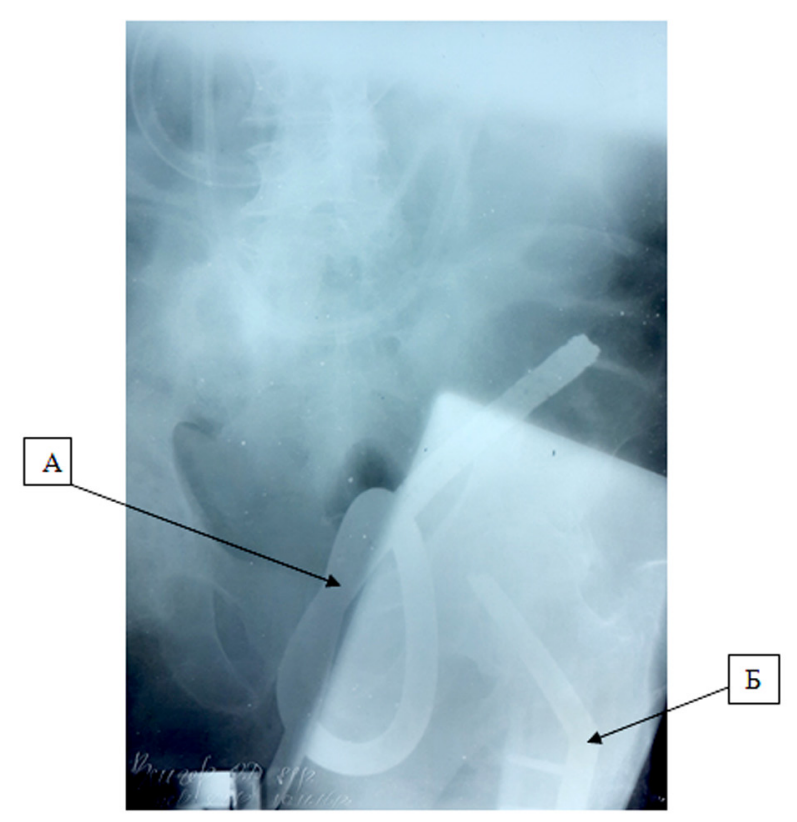

Рис. 1. А - петля колоноскопа, Б - металоостеосинтез лівого кульшового суглоба.

орхектомію зліва, герніопластику пахвинної грижі за Жираром-Спасокукоцьким. Післяопераційний період перебігав без ускладнень. На 8-му добу хворий виписаний із стаціонару.

3. Шевченко Ю. Л. Выбор метода пластики передней брюшной стенки / Ю. Л. Шевченко, С. С. Харнас, А. В. Егоров // Анналы хирургии. - 2003. - № 1. - С. 20-23.

4. Mesh-геinforced hiatal hernia гераir: a review on the effect on postoperative dysphagia and re-currence / S. A. Antoniou, O. O. Koch, G. A. Antoniou [et al.] // Langenbecks Arch. Surg. 2012. - Vol. 397. - P. 19-27.

ence of surgical treatment in patients with post operative anteriolateral hernia]. $A M L X V-A M L X V, 3,84-88$.

3. Shevchenko, Iu.L., Kharnas, S.S., \& Ehorov, A.V. (2003). Vybor metoda plastiki perednei briushnoi stenki [Choice of method of plastics of anterior abdominal wall]. Annaly khirurgii Annals of Surgery, 1, 20-23.

4. Antoniou, S.A., Koch, O.O., Antoniou, G.A. (2012). Mesh-reinforced hiatal hernia repair: a review on the effect on postoperative dysphagia and re-currence. Langenbecks Arch. Surg., 397, 19-27. 
A. D. BEDENIUK, YU. M. FUTUYMA, A.YE. BURAK, O. H. NETSIUK, L. V. BALABAN

I. Horbachevsky Ternopil State Medical University

A CLINICAL CASE OF COLONOSCOPE «JAMMING» IN HERNIA SAC IN PATIENTS WITH LEFT-SIDE INGUINAL HERNIA

The article adduces a unique clinical case, clinical features, diagnosis and surgical treatment of colonoscope “jamming” in hernia sac in patients with left-side inguinal hernia.

Key words: colonscope “jamming”; hernia sac; inguinoscrotal hernia.

БЕДЕНЮК А. Д., ФУТУЙМА Ю. М., БУРАК А. Е., НЕЦЮК О. Г., БАЛАБАН Л. В.

ГВУз “Тернопольский государственный медицинский университет имени И. Я. Горбачевского”

\section{КЛИНИЧЕСКИЙ С.УЧАЙ "УЩЕМЛЕНИЯ" КОЛОНОСКОПА В ГРЫЖЕВОМ МЕШКЕ БОЛЬНОГО С ЛЕВОСТОРОННЕЙ ПАХОВО-МОНОНОЧНОЙ ГРЫЖЕЙ}

В статье представлен уникальный клинический случай, особенности клиники, диагностики и хирургического лечения “ущемления” колоноскопа в грыжевом мешке больного с левосторонней пахово-мошоночной грыжей.

Ключевые слова: “ущемления” колоноскопа; грыжевой мешок; пахово-мошоночная грыжа. 